\title{
And (Always?) Let Your Conscience Be Your Guide
}

JEANNE ELKIN (D)

*Author affiliations can be found in the back matter of this article
凹

Levy

Library

Press

\section{ABSTRACT}

Medical schools that value the moral integrity of their students and that wish to graduate ethical professionals ought to provide a clear process for conscientious objection during clinical rotations.

During clerkship year, medical students are confronted with ethical dilemmas that are complicated by the most profound questions of human existence, including the definition of personhood, the terms that govern creation of a new life, the meaning of suffering, and the finality of death. In these situations, students may draw upon personal experience, prior analysis, cultural beliefs, or religious frameworks in order to decide the most ethical action. These various influences may cause the student to reach a moral conclusion that is at odds with the wish of the patient or the consensus of the medical team. As a current clerkship student, I have personally found myself in several such situations.

Conscientious objection in medicine is the concept that allows providers to refrain from participating in practices that, despite careful study and thoughtful reflection, cannot be reconciled with their moral judgement. This protection also applies - in theory - to medical students, who often find themselves in these same clinical situations.

However, students are not well positioned to practice conscientious objection because:

(1) medical schools do not always make students aware of this option,

(2) students may be afraid to challenge more senior members of the team, and

(3) clerkship success and residency applications rely heavily on subjective evaluations. 
Without institutional support, students may repress strong moral intuitions for these and other reasons. In these instances, medical schools not only miss an opportunity to encourage students to stand up for what they believe to be right, but in fact teach students to ignore the guidance of their conscience in ethically fraught situations.

Schools that wish to encourage the development of ethical professionals should provide a clear and transparent protocol for conscientious objection that empowers students to act in a way consistent with their beliefs, encourages them to think critically about ethical dilemmas, and shows them how to navigate ethical disagreements with compassion and professionalism Figure 1.

\begin{tabular}{|c|c|c|}
\hline $\begin{array}{l}\text { Conscientious Objection: } \\
\text { Protection that confers the ability to } \\
\text { refrain from practices that, despite } \\
\text { thoughtful study, cannot be } \\
\text { reconciled with } \\
\text { "well-considered, deeply held beliefs } \\
\text { that are central to their self-identities" } \\
\text { (AMA 1.1.7) }\end{array}$ & $\begin{array}{l}\text { Barriers for Students: } \\
\text { - Not aware of this option } \\
\text { - } \quad \text { Intimidated by hierarchy } \\
\text { - Subjective evaluations } \\
\text { Problematic Because: } \\
\text { Given these barriers, students may } \\
\text { repress strong moral intuitions } \\
\text { - Missed opportunity to explore } \\
\text { - ethical thought } \\
\text { Probhes to ignore conscience } \\
\text { in ethically fraught situations } \\
\text { with the student's objection }\end{array}$ & $\begin{array}{l}\text { Action Items for Schools: } \\
\text { Make students aware that is an option } \\
\text { Provide clear and transparent protocol } \\
\text { Provide alternatives: } \\
\text { - Short essay on ethical reasoning } \\
\text { or strategies for future practice } \\
\text { - Simulation workshops or lectures } \\
\text { - Alternative clinical experiences } \\
\text { Goal: empower to... } \\
\text { - Act in a way that is consistent } \\
\text { with their beliefs } \\
\text { Think critically about ethical } \\
\text { dilemmas } \\
\text { Navigate ethical } \\
\text { disagreements }\end{array}$ \\
\hline
\end{tabular}

\section{COMPETING INTERESTS}

The author has no competing interests to declare.

\section{AUTHOR AFFILIATION}

Jeanne Elkin (D) orcid.org/0000-0001-5946-3075

Perelman School of Medicine at the University of Pennsylvania, US
ISMMS Journal of Science

and Medicine

DOI: $10.29024 / \mathrm{ijsm} .31$

Figure 1 Poster, presented at the Fifth Annual Medical Student Ethics Conference at Mount Sinai Medical School on December 3rd, 2020. Source: "Code of Medical Ethics Opinion 1.1.7." Physician Exercise of Conscience, American Medical Association, 2020.

TO CITE THIS ARTICLE:

Elkin J. And (Always?) Let Your Conscience Be Your Guide. ISMMS Journal of Science and Medicine. 2021; 1(1): 6, pp. 1-2. DOI: https://doi. org/10.29024/ijsm.31

Submitted: 15 December 2020 Accepted: 15 December 2020 Published: 22 January 2021

\section{COPYRIGHT:}

(C) 2021 The Author(s). This is an open-access article distributed under the terms of the Creative Commons Attribution 4.0 International License (CC-BY 4.0), which permits unrestricted use, distribution, and reproduction in any medium, provided the original author and source are credited. See http://creativecommons.org/ licenses/by/4.0/.

ISMMS Journal of Science and Medicine is a peer-reviewed open access journal published by Levy Library Press. 